\title{
Bioaccumulation of PAHs in Padina boryana Alga Collected from a Contaminated Site on the Red Sea, Saudi Arabia
}

\author{
Huda A. Qari' ${ }^{1}$ Ibrahim A. Hassan ${ }^{2,3 *}$ \\ ${ }^{1}$ Department of Biology, Faculty of Science, King Abdulaziz University, Jeddah, Saudi Arabia \\ ${ }^{2}$ Centre of Excellence in Environmental Studies (CEES), King Abdulaziz University, 21589 Jeddah, Saudi Arabia \\ ${ }^{3}$ Faculty of Science, Alexandria University, 21526 El Shatby, Alexandria, Egypt
}

Received: 4 May 2016

Accepted: 28 June 2016

\begin{abstract}
We used the brown alga Padina boryanawas to determine polyromantic hydrocarbons (PAHs) bioaccumulation at a Jeddah City seashore. We also measured PAHs in the coastal water and in algal tissues using gas chromatography mass spectrometry (GC-MS).

Acenaphthene (Ace) and dibenzo(a,h)anthrancene $(\mathrm{dB}(\mathrm{a}, \mathrm{h}) \mathrm{An})$ were the main PAHs in sea water (50.02 and $46.18 \mathrm{ng} \mathrm{l}^{-1}$, respectively) and in algal tissues (64.67 and $72.45 \mathrm{ng} \mathrm{g}^{-1}$, respectively), respectively. The ratios of low molecular weight/high molecular weight hydrocarbons (1.76-1.44), fluoranthene/pyrene (1.57-1.52), and phenanthrene/anthracene $(0.86-0.67)$ in seawater and algal tissues indicated the origin of PAHs to be mainly pyrogenic.

The high concentrations of PAHs in algal tissues demonstrated the utility of using Padina boryana as a biomonitor of PAH contamination and bioavailability in the coastal waters.
\end{abstract}

Keywords: Polycyclic aromatic hydrocarbons, Padina boryana, bioaccumulation

\section{Introduction}

Living organisms are good accumulators of environmental pollutants and they have been used as bioindicators [1-3]. Sinaei and Mashinchian [4] reported that marine environments are heavily polluted with polycyclic aromatic hydrocarbon (PAH) compounds. PAHs are a group of environmental contaminants formed during the incomplete combustion of organic materials such as coal, fossil fuel, and wood, as well as from forest fires, volcanic activity, and petroleum seeps [5-7].

*e-mail: ihassan_eg@yahoo.com
Seashores that are close to large cities are known to have high concentrations of organic matter such as PAHs due to industrial, aquacultural, and urban activities.

PAHs are of special concern in the marine environment due to their widespread distribution and to the mutagenic and carcinogenic properties of their homologues, among other cytotoxic properties [8-9]. They can be diffused through membranes of marine organisms and accumulate in their tissues, posing a threat to the food chain [10-11]. However, information related to the role of algae in PAH bioconcentration and metabolism are widely scattered in spite of hydrophobic chemicals entering the food-chain by bioconcentration from water into the algae, and algae are capable of accumulating and metabolizing PAHs after 
their bioconcentration [12]. Algae can accumulate PAHs rather than synthesize them [13].

In Saudi Arabia, wastewater is disposed of in the sea; moreover, seashores are stressed by oil pollution and other fossil fuels [3]. In addition, there is a lack of awareness and interest regarding biomonitoring in spite of increasing rates of industrialization and urbanization, as well as an increasing number of motor vehicles [1].

Due to rapid expansion and increasing population and improper management in Jeddah, raw sewage is dumped into the sea, causing serious environmental problems [14]. However, there is scant data about PAH pollution in Jeddah - especially for marine environments.

This study was undertaken to fill the above-mentioned gap of knowledge aimed at investigating the levels of PAHs in the brown alga Padina boryana and water samples collected from the Jeddah seashore, and to assess the bioaccumulation of PAHs by brown algae.

\section{Materials and Methods}

\section{Sampling and Analysis}

Coastal seawater $(1,000 \mathrm{ml})$ was collected in acidwashed amber glass bottles fitted with Teflon screw caps from three different locations. To remove suspended matter, samples were filtered through binder-free glass fiber filters (Whatman GF/C). Filtered samples were stored in pre-cleaned (with deionized water) glass bottles at $4^{\circ} \mathrm{C}$ prior to $\mathrm{PAH}$ analysis [15]. A mixture of $100 \mathrm{ml}$ $\mathrm{n}$-hexane and dichloromethane $(1: 1 \mathrm{v} / \mathrm{v})$ was added to $800 \mathrm{ml}$ water samples and shaken vigorously for $5 \mathrm{~min}$. The water-phase was drained into a 1-L beaker. The organic phase was carefully poured into a glass funnel containing $20 \mathrm{~g}$ of anhydrous $\mathrm{Na}_{2} \mathrm{SO}_{4}$. The water phase was poured back into the separatory funnel for extraction with $50 \mathrm{ml}$ of the same solvent mixture. The extract was concentrated to $2 \mathrm{ml}$ under a gentle stream of nitrogen using a rotary evaporator and then analyzed by GC-MS [11]. The U.S. Environmental Protection Agency (EPA) PAH standard (16 PAHs) was used for identification [16].

Algae (Padina boryana) were collected in plastic bags containing seawater and transported immediately to the laboratory for analysis. Algae were dried at $60^{\circ} \mathrm{C}$ for $48 \mathrm{~h}$ and the dry weight was determined. They were extracted in a Soxhlet-apparatus and analyzed using GC-MS [10].

The limit of detection was $5 \mathrm{ng} \mathrm{l}^{-1}$ for water and $5 \mathrm{ng} \mathrm{g}^{-1}$ for algae [10]. The EPA PAH standard (16 PAHs) was used for identification. Accordingly, the total PAHs describe $\sum 16 \mathrm{PAHs}=$ naphthalene (Nap), acenaphtylene(Acy), acenaphthene (Ace), fluorine $(\mathrm{Fl})$, phenanthrene $(\mathrm{Ph})$, anthrancene (An), fluoranthene(F), pyrene(Pyr), benzo(a)anthrancene (B(a)An), chrysene(Cry), benzo(b) fluoranthene $(\mathrm{B}(\mathrm{b}) \mathrm{F}), \quad$ benzo(k)fluoranthene $(\mathrm{B}(\mathrm{k}) \mathrm{F})$, benzo(a)pyrene(B(a)Pyr), indeno(1,2,3cd)pyrene(I(c,d) Pyr), dibenzo(a,h) anthrancene $(\mathrm{dB}(\mathrm{a}, \mathrm{h}) \mathrm{An})$, and dibenzo(g,h,i)perylene $(\mathrm{dB}(\mathrm{g}, \mathrm{h}, \mathrm{i}) \mathrm{P}$.

\section{Statistical Analyses}

The data obtained were analyzed statistically using Statistical Package for the Social Sciences (SPSS 15) software. The independent sample $t$ test was applied to determine the significant difference between the samples at $\mathrm{p}<0.05$.

\section{Results and Discussion}

Polycyclic aromatic hydrocarbons (PAHs) are ubiquitous in the marine environment, occurring at their highest environmental concentrations around urban centers. While they can occur naturally, the highest concentrations are mainly from human activities, and the primary sources are combustion products and petroleum. Moreover, Jeddah has the main harbor in the kingdom and could present a source of pollution.

Table 1 shows the concentrations of the 16 detected PAHs in surface water and algal tissue and the ratios of low molecular weight to high molecular weight (LMW / HMW) PAH and some selective descriptive congener ratios.

The minimum concentration recorded was related to $\mathrm{B}(\mathrm{k}) \mathrm{F}$, whose mean values were $2.57\left(\mathrm{ng} \mathrm{L}^{-1}\right)$ and $4.41\left(\mathrm{ng} \mathrm{g}^{-1}\right)$ for water and algae samples, respectively. On the other hand, the highest concentration was related to $\mathrm{dB}(\mathrm{h}, \mathrm{h}, \mathrm{i}) \mathrm{P}$, whose mean values were $46.18\left(\mathrm{ng} \mathrm{L}^{-1}\right)$ and $72.45\left(\mathrm{ng} \mathrm{g}^{-1}\right)$ for the same samples, respectively. The mean values of PAH concentrations in water samples and in algae tissues were 298.32ng L-1 and 482.11. $\mathrm{ng} \mathrm{g}^{-1}$, respectively.

Algae tissues had significantly $(\mathrm{p}<0.05)$ higher concentrations of total PAHs (summation of 16 PAHs) than the seawater (Table 1). It is most likely that the large presence of lipids in algae tissues could be the main reason for the observed differences in PAHs.

LMW PAHs represent 63.8 and $59 \%$ of the total PAH in water samples and in algal tissues, respectively, while HMW PAHs present $36.2 \%$ and $41 \%$ in the same samples, respectively (Table 1 ).

Some $\mathrm{PAH}$ ratios were calculated to characterize $\mathrm{PAH}$ mixture and possible sources, including LMW PAHs/ HMW PAHs, F/Pyr and Phen/An (Table 1). The ratios of LMW/HMW were higher than 1.0, which indicated the dominance of LMW PAHs, suggesting petrogenic- and petroleum-related compounds as the main PAH sources [16].

The presence of LMW PAHs in algal tissue could be due to the higher bioavailability of LMW PAHs in the coastal waters $(r=0.79$, data not shown). This could be due to LMW PAHs in the coastal waters being more susceptible to microbial degradation and volatilization and dissolution into the water column [17], thus becoming more bioavailable. Consequently, living tissues were more enriched with LMW PAHs in relation to their environments. The present finding agreed with the results of Isobe et al. [18], who found LMW/HMW ratios $>1.0$ in 
Table 1. Concentrations of the 16 congeners of PAHs in seawater and algae tissues $(n=5 \pm S E)$ and the ratios of concentrations of LMW/HMW $=$ sum of the lower molecular weight PAHs versus sum of the higher molecular weight PAHs; F/Pyr = fluoranthene versus pyrene; $\mathrm{Ph} / \mathrm{An}=$ phenanthrene versus anthracene.

\begin{tabular}{|c|c|c|}
\hline Congener & Water $\left(\right.$ ng $\left.^{-1}\right)$ & $\operatorname{Alga}\left(\mathrm{ng} \mathrm{g}^{-1}\right)$ \\
\hline Nap & $33.45 \pm 4.24$ & $51.03 \pm 5.18$ \\
\hline Acy & $29.45 \pm 2.67$ & $41.18 \pm 6.25$ \\
\hline Ace & $50.02 \pm 6.36$ & $64.67 \pm 5.18$ \\
\hline FI & $15.56 \pm 4.43$ & $33.12 \pm 6.28$ \\
\hline $\mathrm{Ph}$ & $28.56 \pm 5.27$ & $37.92 \pm 4.56$ \\
\hline An & $33.34 \pm 6.58$ & $56.33 \pm 5.12$ \\
\hline $\mathrm{F}$ & $7.34 \pm 0.67$ & $13.56 \pm 2.56$ \\
\hline Pyr & $4.67 \pm 0.67$ & $8.91 \pm 1.35$ \\
\hline $\mathrm{B}(\mathrm{a}) \mathrm{An}$ & $5.43 \pm 2.45$ & $13.56 \pm 3.16$ \\
\hline Cry & $6.04 \pm 0,23$ & $10.46 \pm 0.94$ \\
\hline $\mathrm{B}(\mathrm{b}) \mathrm{F}$ & $5.67 \pm 0.67$ & $11.35 \pm 2.10$ \\
\hline $\mathrm{B}(\mathrm{k}) \mathrm{F}$ & $2.57 \pm 0.56$ & $4.41 \pm 0.92$ \\
\hline B(a)Pyr & $7.24 \pm 1.12$ & $12.78 \pm 2.18$ \\
\hline $\mathrm{I}(\mathrm{c}, \mathrm{d}) \mathrm{Pyr}$ & $18.93 \pm 2.46$ & $44.37 \pm 7.29$ \\
\hline $\mathrm{dB}(\mathrm{a}, \mathrm{h}) \mathrm{An}$ & $3.87 \pm 0.87$ & $6.01 \pm 1.04$ \\
\hline $\mathrm{dB}(\mathrm{h}, \mathrm{h}, \mathrm{i}) \mathrm{P}$ & $46.18 \pm 7.67$ & $72.45 \pm 11.46$ \\
\hline LMW PAHs & $190.38(36 \%)$ & $284.25(41 \%)$ \\
\hline HMW PAHs & $107.94(64 \%)$ & $197.86(59 \%)$ \\
\hline$\Sigma \mathrm{PAHs}$ & 298.32 & 482.11 \\
\hline \multicolumn{3}{|c|}{ Ratios } \\
\hline $\begin{array}{c}\text { LMW PAHs/HMW } \\
\text { PAHs }\end{array}$ & 1.76 & 1.44 \\
\hline $\mathrm{F} / \mathrm{Pyr}$ & 1.57 & 1.52 \\
\hline Phen/An & 0.86 & 0.67 \\
\hline
\end{tabular}

many Asian countries. Skarpheðinsdottir et al. [19] also reported that blue mussels collected close to ports had relatively higher levels of LMW PAHs. Baumard et al. [20] found that the blue mussels sampled in the western Baltic Sea were enriched in LMW PAHs. Thus, the presence of higher LMW PAHs in marine biota is due to their ability to be selectively uptaken [16].

The main anthropogenic PAH sources are spillage of petroleum and fossil fuels [15]. The sources of PAHs, whether from fuel combustion (pyrolytic) or from sediment, could be of pyrogenic sources. The petrogenic contamination may be identified by ratios of individual PAH compounds based on peculiarities in $\mathrm{PAH}$ composition and distribution pattern as a function of the emission source. The ratio of phenanthrene to anthracene $(\mathrm{Ph} / \mathrm{An})$ and fluoranthene to pyrene (F/Pyr) have been widely used to distinguish petrogenic and pyrogenic (pyrolytic) sources of PAHs [15]. PAHs of petrogenic origin are generally characterized by $\mathrm{Ph} / \mathrm{An}$ values $>10$, whereas combustion processes often result in low $\mathrm{Ph} / \mathrm{An}$ ratios $(<10)$. For the $\mathrm{F} / \mathrm{Pyr}$ ratios, values greater than 1 have been used to indicate pyrolytic origins and values less than 1 are attributed to petrogenic sources [15].

In our study, F/Pyr ratios were found to be 1.57 and 1.52 in seawater and in algae tissue, respectively (Table 1). These ratios indicate pyrogenic sources [21]. Moreover, the $\mathrm{Ph} / \mathrm{An}$ ratios were 0.86 and 0.67 for the same samples, respectively, (Table 1), and they also indicated a pyrogenic origin. It should be noted that pyrolytic PAHs are mainly anthropogenic, which could be due to industrial activities. Since there are many petroleum industries and other industrial activities are available in the city, PAH transport via atmospheric aerosols and particles could be considered as one of the pyrogenic inputs. Our results indicated that PAHs originated mainly from pyrolytic sources, as indicated by LMW/HMW and F/Pyr ratios, and this is in agreement with previous results in Malaysia [16, 21], Iran [15], Iraq [22], and China [23]. An F/Pyr ratio greater than 1 indicates the dominance of the combustion-derived material (i.e., of pyrolytic origin) [24]

Fig. 1 shows that there were significant differences in the concentrations of PAHs in water and algae samples among seasons $(\mathrm{P}<0.01)$. The highest concentrations were recorded in summer (301.32 $\mathrm{ng} \mathrm{l}^{-1}$ ) for water and $\left(507.28 \mathrm{ng} \mathrm{g}^{-1}\right)$ for algae tissues, while the lowest concentrations were recorded in spring. Concentrations of PAHs were $101.34 \mathrm{ng} \mathrm{l}^{-1}$ and $235.35 \mathrm{ng} \mathrm{g}^{-1}$ for the same samples, respectively. Such variations could be attributed to such climatic conditions as volatilization and high degradation during the hot season [22, 25-27]. The presence of HMW PAHs (e.g., dB(a,h)An) could indicate that colloidal oil droplets occur in water [24].

The presence of PAHs in marine water combined with other potentially toxic compounds could result in negative effects. The leakage of oils, oily wastes, and mixtures can

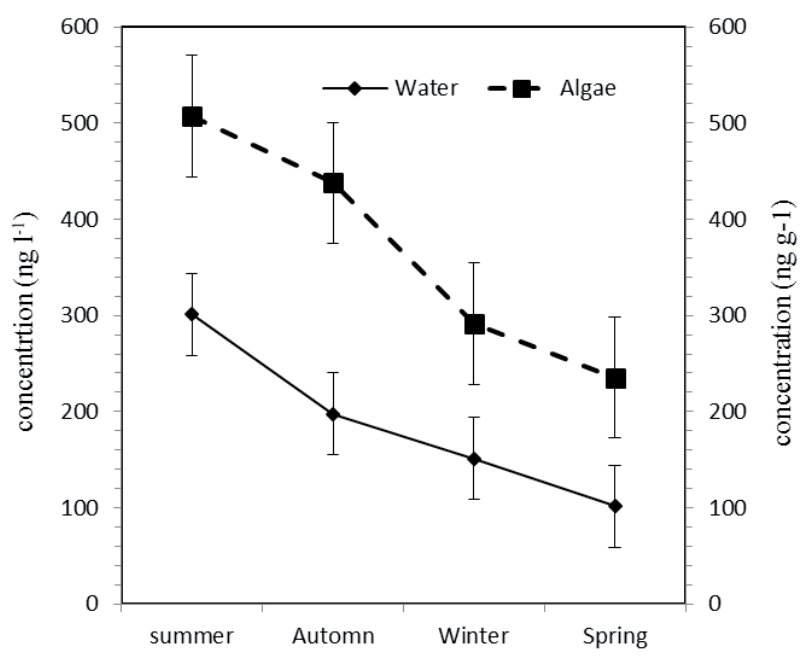

Fig. 1. Comparison of mean PAH concentrations in water and algae tissue samples in different seasons. 
directly cause damage to fishery resources, aquatic biota, and coastal habitat. These effects may seriously damage marine and coastal ecology.

\section{Conclusions}

The higher concentrations of PAHs that were found in seawater and algae tissues could be due to domestic waste and being near the port. These inputs would pose a threat to the marine ecosystem [16].

Based on ratios of LMW/HMW and F/Pyr, it was found that the main origin could be a pyrogenic source. However, there were significantly $(p<0.05)$ higher concentrations of PAHs in the algal tissues of Padina boryana collected from the coastal water. In general, the results also indicated that $P$. boryana was useful for biomonitoring PAH contamination and bioavailability in coastal water.

\section{Acknowledgements}

We would like to thank Mr Essam Khoder for his continuous support and help.

\section{References}

1. HASSAN I.A., BASAHI J. Assessing roadside conditions and vehicular missions using roadside lettuce plants. Polish J. Environ. Studies, 22 (2), 75, 2013.

2. AL MEELEBI T., ISMAIL I., BASAHI J., QARI H.A., HASSAN I.A. Hazardous of wastewater irrigation on quality attributes and contamination of citrus fruits. Bioscience Biotech. Research, 11 (1), 89, 2014.

3. QARI A.H., HASSAN I.A. Removal of pollutants from wastewater using Dunaliella Algae. Biomedical Phrma. J., 7 (1), 147, 2014.

4. SINAEI M., MASHINCHIAN A. Polycyclic aromatic hydrocarbons in the coastal seawater, the surface sediment and Mudskipper Boleophthalmus dussumieri from coastal areas of the Persian Gulf: source investigation, composition pattern and spatial distribution. J Environ Health Sci Eng., 12, 59, 2014.

5. OROS D.R., ROSS J.R. Polycyclic aromatic hydrocarbons in San Francisco Estuary sediments. Mar Chem., 86, 169, 2008.

6. NEFF J.M. Polycyclic aromatic hydrocarbons in the aquatic environment. Sources, fates and biological effects. Barking, Essex, UK: Applied Science. 262. 2008.

7. YUNKER M.B., MACDONALD R.W., VINGARZAN R., MITCHELL R.H., GOYETTE D., SYLVESTRE S. PAHs in the Fraser River basin: a critical appraisal of PAH ratios as indicators of PAH source and composition. Org Geochem., 33, 489, 2012.

8. TOLOSA I., STEPHEN J., MORA D., SCOTT W., VILLENEUVE J.-P., BARTOCCI J., CATTINI C. Aliphatic and aromatic hydrocarbons in marine biota and coastal sediments from the Gulf and the Gulf of Oman. Mar. Pollut. Bull., 50, 1619, 2009.

9. LEÓN V., GARCÍA I. MARTÍNEZ-GÓMEZ C. CAMPILLO J.A. BENEDICTO J. Heterogeneous distribution of polycyclic aromatic hydrocarbons in surface sediments and red mullet along the Spanish Mediterranean coast. Marine Pollut. Bullt., 87 (1-2), 352, 2014.

10. HYÖTYLÖINEN T., OIKARI A. Bioaccumulation of PAHs from creosote-contaminated sediment in a laboratoryexposed freshwater oligochaete, Lumbriculuc varigatus. Chemosphere, 57, 159, 2008.

11. DUAN D., HUANG Y., CHENG H., RAN Y. Relationship of polycyclic aromatic hydrocarbons with algae-derived organic matter in sediment cores from a subtropical region. J. Geophysical Res., 120 (11), 2243, 2015.

12. AN-PING L., ZHANG-LI H., YUK-SHAN W. Bioconcentration and Metabolism of Polycyclic Aromatic Hydrocarbons (PAHs) by Algae. Plant Science J., 23 (3), 291, 2008

13. MAGI E.R., BIANCO C., IANNI M., CARRO D.I. Distribution of polycyclic aromatic hydrocarbons in the sediments of the Adriatic Sea. Environmental Pollution, 119, 91, 2012.

14. AL-FARAWTI R.K., EL-MARADENYA., NIAZ G.R. Fecal sterols and phases in sewage polluted marine environment along the Eastern Red sea, south of Jeddah Saudi Arabia. Ind. J. Marine Sci., 38 (4), 404, 2009.

15. KAFILZADEH F., SHIVA A.H., MALEKPOUR R. Determination of Polycyclic Aromatic Hydrocarbons (PAHs) in Water and Sediments of the Kor River, Iran. Middle-East J.Sci Res., 10 (1), 01, 2011.

16. YAP C.K., SHAHBAZI A., ZAKARIA M.P. Concentrations of Heavy Metals $(\mathrm{Cu}, \mathrm{Cd}, \mathrm{Zn}$ and Ni) and PAHs in Perna viridis Collected from Seaport and Non-seaport Waters in the Straits of Johore. Bulletin Env. Contam.,Toxic., 89 (6), 1205, 2102.

17. ZAKARIA M.P., TAKADA H., HORINOUCHI A., TANABE S., ISMAIL A. Application of biomarkers for source identification of oil pollution in the Straits of Malacca, Malaysia. Environ Sci Technol. 34, 1189, 2010.

18. ISOBE T., TAKADA H., KANAI M., TSUTSUMI S., ISOBE K.O., BOONYATUMANOND R., ZAKARIA M.P. Distribution of polycyclic aromatic hydrocarbons (PAHs) and phenolic endocrine disrupting chemicals in South and Southeast Asian mussels. Environ Monitor Assess, 135, 423, 2007.

19. SKARPHEĐINSDOTTIR H., ERICSON G., SVAVARSSON J., NÆS K. DNA adducts and polycyclic aromatic hydrocarbon (PAH) tissue levels in blue mussels (Mytilus spp.) from Nordic coastal sites. Mar Environ Res, 64, 479, 2007.

20. BAUMARD P., BUDZINSKI H., GARRIGUES P., DIZER H., HANSEN P.D. Polycyclic aromatic hydrocarbons in recent sediments and mussels (Mytilus edulis) from the Western Batlic Sea: occurrence, bioavailability, and seasonal variations. Mar Environ Res., 47, 17, 1999.

21. YAP C.K., MASHINSHIAN M.A., ISMAIL A., ZAKARIA M. Relationships and comparative studies of heavy metals and organic PAH compounds in the soft tissues Perna viridis. Res J Chem Environ., 14 (1), 56, 2010.

22. MOHAMMED A.B., AL-TAEE M.M.S., HASSAN F.M. The study of some PAH compounds in Euphrates River sediment from Al-Hindiya Barrageto Al-Kifil city, Iraq. Scientific Conference, College of $4^{\text {th }}$ Science, Babylon University. CSASC English Ver., 4, 216, 2009.

23. QIU Y.W., G. ZHANG G.Q. LIU L.L. GUO X.D.L., WAI I.O. Polycyclic aromatic hydrocarbons (PAHs) in the water column and sediment core of Deep Bay, South China. Estuarine, Coastal and Shelf Sci., 83, 60, 2009. 
24. AHMED EL NEMR A., ABD-ALLAH A. M.A. Contamination of polycyclic aromatic hydrocarbons (PAHs) in microlayer and subsurface waters along Alexandria coast, Egypt. Chemosphere, 52: 1711 -1716, 2003. http:// dx.doi.10.1016/S0045-6535(03)00300-X

25. HARRISON R., ASLAM S., DANG J., BASAHI J., ALGHAMDI M., ISAMIL I., HASSAN I., KHODER M. Influence of petrochemical installations upon PAH concentrations at sites in Western Saudi Arabia. Atm. Pollut. Research http://dx.doi.org/10.1016/j.apr.2016.05.2016.
26. HAIBA N., HASSAN I.A. Monitoring and assessment of PAHs in the atmosphere of Alexandria city, Egypt. Polycyclic Aromatic Compounds. http://dx.d oi10.1080/10406638.2016.1200102.2016.

27. HARITASH A.K., KAUSHIK C.P. Biodegradation aspects of polycyclic aromatic hydrocarbons (PAHs): A review. J. Haz. Mat., 169 (1-3), 1, 2009. 
